\title{
Logistics opportunity costs: A mining case study
}

\begin{abstract}
Authors:
Leani van Jaarsveld ${ }^{1}$

Gert J. Heyns ${ }^{2}$

Peter J. Kilbourn ${ }^{2}$

Affiliations:

${ }^{1}$ Department of Transport and Supply Chain

Management, University of

Johannesburg, South Africa

${ }^{2}$ Institute of Transport and

Logistics Studies (Africa),

University of Johannesburg,

South Africa
\end{abstract}

\section{Correspondence to:}

Gert Heyns

Email:

gjheyns@uj.ac.za

Postal address:

PO Box 524, Auckland Park

2006, South Africa

Dates:

Received: 24 Aug. 2013

Accepted: 27 Sept. 2013

Published: 12 Nov. 2013

How to cite this article:

Van Jaarsveld, L., Heyns,

G.J \& Kilbourn, P.J. 2013,

'Logistics opportunity costs:

A mining case study', Journa

of Transport and Supply

Chain Management 7(1),

Art. \#120, 11 pages. http://

dx.doi.org/10.4102/jtscm.

v7i1.120

\section{Copyright:}

(C) 2013. The Authors.

Licensee: AOSIS

OpenJournals. This work

is licensed under the

Creative Commons

Attribution License.

Read online:
This study highlighted the importance of determining the impact that an ineffective mode of transport has on a firm's transportation model and costs. The main focus of this study was to determine the logistics opportunity costs of using road transport within a mining firm. A case study approach was followed, as the investigation aimed to analyse a complex problem experienced by one company and present it in an easily understandable format. From the results of this study, it was apparent that the logistics opportunity costs associated with the mode of transport was substantial. This highlighted the need for firms to revise their choice of transport mode on a regular basis, as it has a major impact not only on their transportation costs, but also on their inventory holding and carbon emissions. The results also have implications for South Africa's only freight railway, Transnet Freight Rail, which should not only focus on expanding its existing capacity, but also on improving its customer service delivery whilst containing tariff increases.

\section{Introduction}

Transport plays a pivotal role within the South African economy as it enables the country to achieve economic growth and development. The transport industry does not only facilitate the movement of freight and people, it also employs a great number of individuals and forms a major part of South Africa's Gross Domestic Product (GDP). The 9th Annual State of Logistics Survey for South Africa indicated that transport costs were accountable for $7.7 \%$ and $7.8 \%$ of the country's GDP in 2011 and 2012 respectively (Havenga \& Simpson 2013). The importance of the transport industry makes it imperative that the industry is operated efficiently and effectively.

Transport mode choices are usually based on many different factors, including: the transit time, reliability, accessibility, capability, and security or safety levels inherent in a specific mode of transport. Transport is, however, one of various interdependent components that form a logistics system. For this reason, transport mode choices should not only be made based on transportation costs but rather on total logistics costs (Pienaar \& Vogt 2012).

Opportunity costs should be considered when calculating total logistics costs. Different forms of opportunity costs exist within a logistics system; these include the opportunity cost associated with poor service levels, holding inventory, delays, lost sales and returning a vehicle without a backhaul.

In recent years, due to the inadequacies associated with rail transport provision in the country, many firms in South Africa have been making use of road transport as an alternative to rail transport to move freight. The shortage of investment in rolling stock over many decades, which has only recently been reversed, has had a significant impact on rail service delivery (Havenga \& Pienaar 2012). Due to the different service and cost characteristics associated with rail and road transport, mode selection has an impact on the total logistics costs of a firm. The impact will vary from industry to industry, due to the inherent different service and costs implications.

The selection of road transport as an alternative to rail transport will result in a total logistics costs differential. Thus, a definite need exists to determine the logistics opportunity costs of using road transport as an alternative to rail transport for certain commodities.

This study specifically focused on the logistics opportunity costs of using road transport for a firm in the mining industry. Firm $\mathrm{A}^{1}$ is a mining and production company that has its main operations within two of South Africa's provinces. The firm's mining output is used in paper and pulp, paints and plastics, and it supplies its products to the gold, steel, platinum and water purification industries.

1.The firm requested to remain anonymous and so the pseudonym, Firm A, is used. 
Firm A operates two distinct supply chains from its mining facilities. One supply chain originates with the extraction of raw materials from its mine in the Northern Cape, which are processed into a semi-finished industrial product. The coal that is required for this process is sourced from a coalmining supplier. Once the semi-finished product has been processed, it gets packaged and is sent directly to customers. This supply chain is depicted in Figure 1.

The firm also manufactures finished products at a manufacturing plant located in Gauteng, from where it distributes the goods to its customers. This different supply chain is also depicted in Figure 1.

Until the end of 2008, both supply chains predominantly used rail transport for the haulage of mining output from the processing plant both directly to customers and to the manufacturing facility. As a result of frequent service disruptions, the use of rail transport declined from 100\% in 2008 to $53 \%$ in 2011.

Firm A's shift from rail to road transport was due to problems experienced with Transnet Freight Rail (TFR), including poor service levels due to a regular shortage of available rolling stock (wagons and locomotives). Transnet Freight Rail has also moved away from single wagon despatches and operates block trains of 40 wagons and more. Revised train driver working hours resulted in trains regularly stopping en-route for driver changeovers, which caused service disruptions. In addition, continuous theft of tarpaulins, cables and signalling systems has made the service unreliable, and Firm A's product cannot be moved without tarpaulins in place. Theft of cables and signals has also caused unplanned delays.

Poor service delivery by TFR jeopardised the continuous supply of feeder stock from the mine and processing plant in the Northern Cape to the manufacturing facility. As a result, the firm has increasingly turned to road transport for the haulage of raw materials and products. This modal shift has directly impacted on its logistics costs through: higher transport rates; the necessity to acquire an additional property adjacent to its manufacturing facility to deal with the increased number of road tippers required to deliver the mining extract; needing to develop a new financial system to deal with the increased number of invoices; and having to employ additional staff to facilitate the required transport management activities.

The primary purpose of this research was to analyse the logistics opportunity costs associated with Firm A's decision

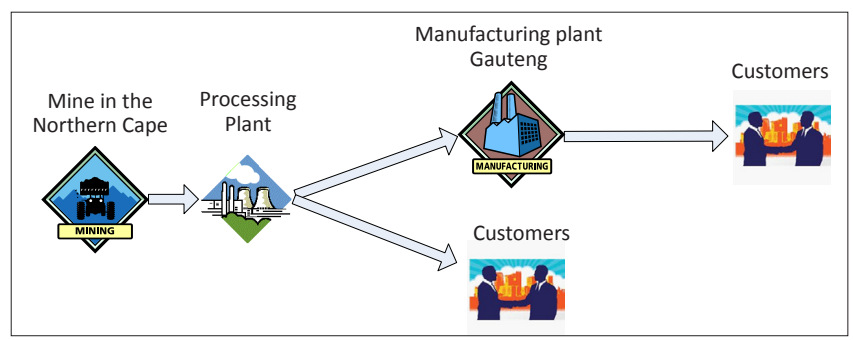

FIGURE 1: The distinct supply chains of Firm A. to change the dominant mode of transport (modal shift from rail to road transport) for its mining supply chain.

\section{Literature review}

Since the 1930s, freight rail transport has lost market share against a rapidly developing road transport industry (Van der Mescht 2006). This is despite The Motor Carrier Transportation Act 39 of 1930 (Republic of South Africa 1930) allowing rail protection against road freight competition (Havenga \& Pienaar 2012). More recently, the Department of Transport (DoT) referred to the inefficiencies and poor service reliability of rail transport, in particular in its National Freight Logistics Strategy (Department of Transport 2005b:12). It furthermore stated that the main reasons for this phenomenon were the ageing asset base, a culture of poor service delivery, as well as lack of accountability for low efficiencies.

The Road Freight Strategy for South Africa (Department of Transport 2011:1) highlights the fact that South Africa's transportation costs are considerably higher than most other economies and that they need to be minimised. As transport costs are directly linked to the oil price, it is a very vulnerable cost and could therefore continue to escalate. The prospect of additional tolling costs, as well as the possibility of the taxing of carbon emissions, would further ensure that transport costs' share of the total logistics spend will increase in the future (Havenga, Simpson \& De Bod 2012).

The South African road freight industry has shown rapid growth since the industry was fully deregulated through the Transport Deregulation Act 80 of 1988 (Republic of South Africa 1988). This allowed for unrestricted movement of goods on South African roads and placed road transport in a more favourable position to compete directly with rail transport.

The disparity between the share of freight volume that road and rail transport enjoy in South Africa is evident when considering that the estimated share of the land freight tonnage moved by road transport was $88.5 \%$ of total tonnages of freight moved in 2012, whilst rail transport was accountable for only $11.5 \%$ (Havenga \& Simpson 2013).

In 2011, Transnet identified four key risk areas that negatively influence its volumes: operational efficiencies, financial performance, safety and human capital (Transnet 2011:128):

- The first area, productivity efficiency risk, relates to the ageing rolling stock and infrastructure, which has resulted in Transnet not being able to move its planned volumes. This has reduced its operating efficiencies and increased its revenue loss.

- The second area, human capital risk (competency), implies that they have a shortage of skills in their workforce, which has led to poor organisational performance.

- The third area, industrial relations risk, refers specifically to the strike actions experienced in 2010, which hampered its ability to deliver. 
- The fourth and final area, capital project risk, implies that they have been ineffective in implementing and executing capital projects.

However, Transnet moved record volumes of freight during the 2012 financial year. It showed a total growth of $10.4 \%$ on the previous year and achieved 201 million tons of freight volume. These improved results followed major capital investments in maintaining, replacing and expanding rail infrastructure over the past decade, as depicted in Figure 2 (Transnet 2012a).

The capital investments that were made are encouraging for future growth in rail volumes. It is, however, important for TFR not only to focus on expanding available capacity, but also to focus on improving its service delivery to its customers. Ultimately, poor service delivery is the main factor leading to firms moving their goods off rail and onto the road.

Transnet's recently launched Market Demand Strategy (MDS), supported by a R300 billion capital project programme that will run over seven years, aims to increase the current capacity of their general freight, coal and iron ore business. This will significantly assist in the reduction of the cost of doing business and facilitate the shift from road to rail transport (Transnet 2012b).

The rapid growth of the road transport industry over recent decades has caused South African roads to deteriorate rapidly, as the majority of South Africa's roads have reached the end of their design life. It implies that major investment is necessary to restore the condition of the roads as well as to expand the current infrastructure to cope with the growth in transport demand. Unfortunately, the maintenance and repair of roads has not received the necessary attention, to the extent that the maintenance backlog for South African roads is estimated to be R149 billion (SABITA 2012).

Business Unity South Africa (BUSA 2011) recently discussed the poor state of South African roads and the impact it has on the logistics costs of firms. It stated that the poor state of roads could be attributed to:

- the increased number of heavy freight vehicles,

- the over-loading of these vehicles,

- insufficient funds allocated for road maintenance,

- the poor quality of road construction and

- transport operators using provincial roads not equipped for heavy vehicles in order to avoid toll fees.

The growth in the number of road freight vehicles is illustrated by the electronic national administration traffic information system's (eNatis) vehicle count reports. Figure 3 shows the increase in the number of vehicles on South African roads between 2007 and 2011. Vehicles with a Gross Vehicle Mass (GVM) of less than $3500 \mathrm{~kg}$ are illustrated on the primary axis and vehicles with a GVM of more than $3500 \mathrm{~kg}$ are illustrated on the secondary axis (eNatis 2007-2012).

As depicted in Figure 3, the number of GVM $\leq 3500 \mathrm{~kg}$ vehicles in South Africa has grown by $13.8 \%$ over the period

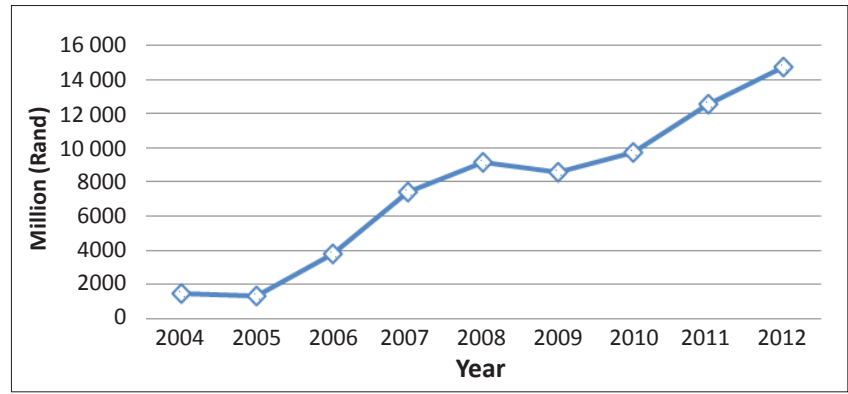

Note: Please see the full reference list of the article, Van Jaarsveld, L., Heyns, G.J. \& Kilbourn P.J. 2013, 'Logistics opportunity costs: A mining case study', Journal of Transport and Supply Chain Management 7(1), Art. \#120, 11 pages. http://dx.doi.org/10.4102/jtscm.v7i1.120, for more information.

FIGURE 2: Capital investments.

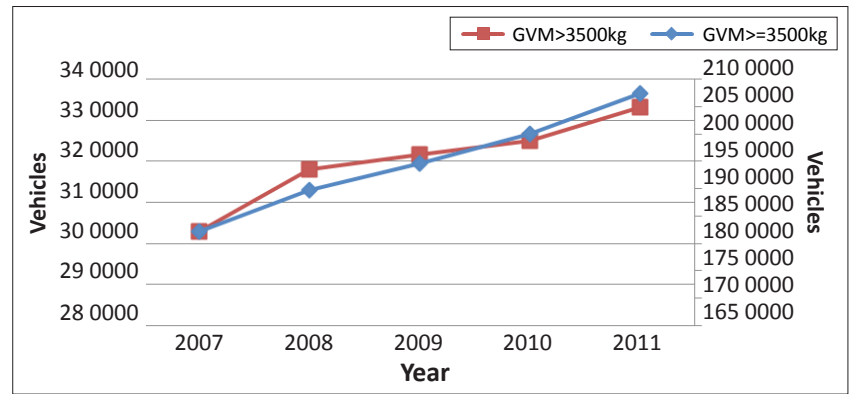

Source: eNatis, 2007-2012, Live vehicle population, viewed 06 July 2012, from http://www. enatis.com

FIGURE 3: eNatis live vehicle count 2007-2011.

2007-2011. For vehicles with a GVM > $3500 \mathrm{~kg}$, volume growth of $10 \%$ was experienced during the period 2007-2011. The increase in vehicle numbers and road freight volumes is indicative of the preference for road freight transport over rail transport.

Firms consider various modal attributes when selecting the most suitable transport mode for their operational requirements, these include: reliability, flexibility, accessibility, availability, time in-transit and cost (refer to Table 1).

From a firm's perspective, the choice of transport mode has an impact on total logistics costs, which makes it necessary to consider different cost trade-offs. Key strengths of road transport compared to rail transport include shorter transit times, higher frequency and reliability of service (Pienaar \& Vogt 2012). Generally, road transport allows firms to reduce stock levels and react quicker to changing customer demand. Substituting rail with road transport usually results in higher transportation costs, but lower inventory costs (Coyle et al. 2013). According to Chopra and Meindl (2010), lower cost transport modes typically have longer lead times and larger minimum shipment quantities, which result in higher inventory levels. The reduced inventory holding and storage costs benefit might be associated with higher transport costs. From a macro-economic perspective, the predominant use of road transport not only results in higher total national logistics costs, but also increases related social and externality costs such as the faster deterioration of South African roads, increased congestion and noise, more 
TABLE 1: Factors that affect freight modal choice.

\begin{tabular}{ll}
\hline Factor group & Factor \\
\hline Total logistics costs & Order and handling costs \\
& Transportation charges \\
& Loss and damage costs \\
& Capital carrying cost in transit \\
& Unavailability of equipment costs \\
& Service reliability costs \\
& Intangible service costs \\
& Inventory carrying cost \\
Physical attributes of goods & Shipment size \\
& Package characteristics \\
& Shipment shelf life \\
& Shipment value \\
Flow and spatial distribution & Shipment density \\
& Shipment frequency \\
Modal characteristics & Distance of shipment \\
& Capacity \\
& Trip time and reliability \\
Equipment availability \\
Customer service \\
Handling quality \\
\hline
\end{tabular}

Source: Adapted from University of South Florida, n.d., Analysis of Freight Movement Mode Choice Factors, viewed 26 August 2012, from http://www.dot.state.fl.us/rail/Publications/ Studies/Planning/ModeChoiceFactors.pdf

accidents and environment pollution from increased carbon emissions (Swarts et al. 2012).

As alluded to previously, opportunity costs should also be considered when choosing a mode of transport. Opportunity cost is a term that is widely used within the accounting and finance spheres. Atrill and McLaney (2008:491) defined opportunity cost as 'the cost incurred when one course of action prevents an opportunity to derive some benefit from another source of action'. For example, if money is invested, the opportunity to use that money for an alternative action to derive a benefit from it is lost, such as taking that same money and putting it in the bank to earn interest.

From a supply chain perspective, numerous definitions are used to explain opportunity cost, which predominantly focus on the cost of capital tied up in inventory, as follows: Lambert, Stock and Ellram (1998:153) explained opportunity cost as 'the rate of return that could be realised from some other use of money'. Coyle, Bardi and Langley (2003:198) used the term opportunity cost as part of their inventory carrying cost calculation and define it by asking 'what is the implicit value of having capital tied up in inventory, instead of using it for some other worthwhile project?' Anupindi, Chopra et al. (2006:140) defined opportunity cost as 'the foregone return on the funds invested in inventory which could have been invested in alternate projects'. Gattorna and Walters (1996:128) explained that opportunity cost arises when too much capital is invested in one aspect of a business resulting in a lack of capital available to invest in alternatives.

Sahay, Cavale and Mohan (2003:96) indicated that if a company does not hold sufficient inventory, it could result in the opportunity cost of lost business, resulting in lost revenue for the company. However, holding excessive inventory could result in the opportunity cost of funds being tied up in inventory and possible obsolescent inventory. Therefore, a detailed analysis of the opportunity cost trade-offs is required to determine the optimum level of inventory for firms.

Within a supply chain there are many cost components, and therefore, opportunity costs should not be applied solely to the cost of carrying inventory. Logistics opportunity costs could be expanded to include many other aspects within the supply chain. Recent studies applying opportunity costs within the different areas within supply chain management include: the opportunity cost of keeping inventory indicates that capital is tied up in inventory and it is therefore a foregone opportunity to use that capital elsewhere in the business (Wajcharapornjinda \& Chiadamrong 2010); the opportunity cost associated with poor levels of service (Satar \& Peoples 2010); the opportunity cost of returning a vehicle without a backhaul (Behrens \& Picard 2011); the opportunity costs (or idle costs) when manufacturing equipment is underutilised (Wajcharapornjinda \& Chiadamrong 2010); opportunity costs due to transportation delays (Bromley \& Foltz 2011); the opportunity cost of keeping inventory and the opportunity cost of lost sales (Wajcharapornjinda \& Chiadamrong 2010; Osorio \& Toro 2012).

Therefore, opportunity costs come in many forms within the supply chain and it is imperative for firms to consider not only the visible costs, but also the invisible (or hidden) costs when making a transport mode decision.

\section{Research methodology}

The main purpose of this study was to determine the logistics opportunity costs of using road transport within a mining firm that is typically more suitable for rail transport due to the bulk nature of its product, high volumes and the relatively long distances over which products must be transported.

The case study approach that was followed in this study required that:

- Firm A's logistics operations costs be described and calculated for the period in which rail was the predominant mode of transport utilised in its operation (2006-2009).

- A discussion be held about Firm A's operational decisions to incorporate road transport.

- Logistics costs be described and analysed from the time the decision was made to incorporate road transport as a major contributor to its logistics operations (2009-2011).

- A comparison be done of the two scenarios, and the logistics opportunity costs of using road transport be determined.

- The financial position of Firm A be analysed against varying levels of inventory investments as an alternative strategy to increased road transport cost.

A case study provides an in-depth analysis of a specific situation, which results in an enhanced understanding of the circumstances (Burton \& Bartlett 2005). The case study framework that was used in determining the logistics opportunity costs is depicted in Figure 4. 


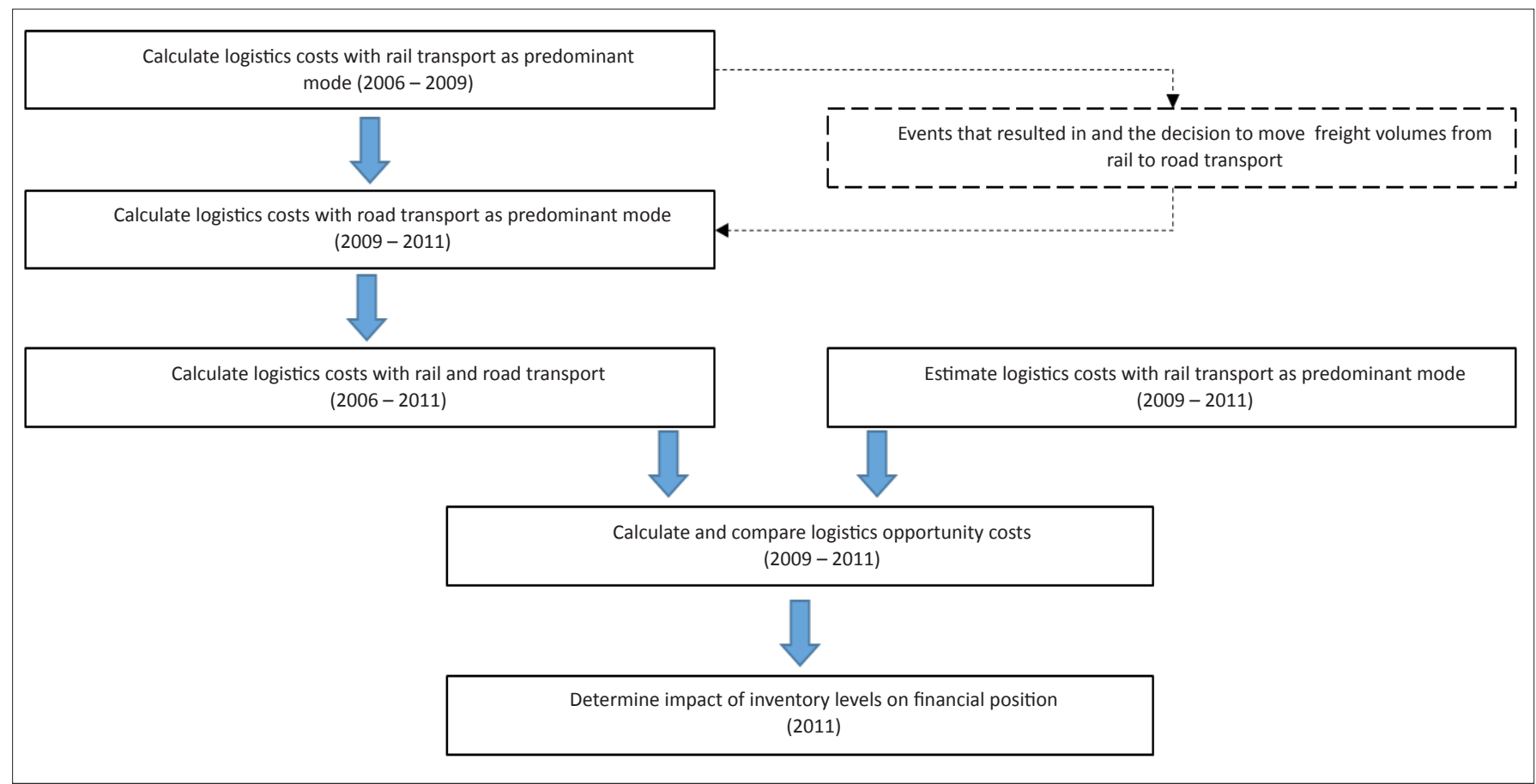

FIGURE 4: Framework for determining Firm A's logistics opportunity costs.

The total logistics cost is calculated and analysed by making use of the following formula:

$\mathrm{TLC}=\mathrm{TC}+\mathrm{SC}+\mathrm{MAP}+\mathrm{ICC}$

[Eqn 1]

Where: $\quad$ TLC $=$ Total logistics cost

$\mathrm{TC}=$ Transport cost

SC $=$ Storage and port handling cost

$\mathrm{MAP}=$ Management, administration and profit cost ICC $=$ Inventory carrying cost.

The Council for Scientific and Ind ustrial Research (CSIR) used this formula, which excludes opportunity cost, to determine the national logistics costs for South Africa (Havenga 2010: 466-70). Profit cost was omitted from the logistics cost calculations, as it is not a business objective of the firm to make a profit from its logistics function. The logistics opportunity cost was calculated by determining the logistics costs for both road and rail transport and by multiplying the cost differential by the firm's weighted average cost of capital (WACC).

An assumption was made that the logistics cost difference for a specific year would only result in an opportunity cost during the following year. The following future value (FV) formula was used to determine the opportunity costs for each year's logistics cost differential (Du Toit, Erasmus, Kotzé, Ngwenya, Thomas \& Viviers 2010:98):

$\mathrm{FV}_{n}=\mathrm{PV}_{0} \times(1+i / m)^{n \times m}$

Where: $\mathrm{FV}_{n}=$ Future Value at the end of period $n$

$\mathrm{PV}_{0}=$ Present Value at period $\mathrm{T}_{0}$

$i=$ Rate of interest paid or earned per period

$n=$ Total number of periods of the investment

$m=$ Number of times interest is compounded perperiod.
The strategic profit model (SPM) was further used to determine the impact of the choice of transport mode on the firm's financial position and to determine the inventory level for the company resulting from not using road transport. The SPM is a methodology that can be used to determine the profitability impact of a firm's decisions. The SPM makes use of data reflected on a firm's income statement and balance sheet to determine, amongst other things, the firm's profitability. The SPM enables a firm to determine how inventories, investments in fixed assets, operating expenses, changing transportation costs and so on, affect the firm's net income, its capital employed and the return on capital employed (Langley et al. 2008).

By using historical data, a firm can trace its performance over a number of years in order to determine whether the firm's performance has improved or whether it has deteriorated. The SPM tool can be used to point out problem areas that are affecting the firm's performance. The SPM ratios can further be used as a benchmarking tool to compare the firm against similar firms within the industry. For the purpose of this study, the SPM is used to analyse the impact of using road transport as an alternative to rail transport.

To determine the environmental impact of the choice of transport mode, an activity-based approach was followed, as all the relevant energy data for rail transport was not available to use the energy-based approach. Even though the energy-based approach provides more accurate carbon emissions, the activity-based approach provides a realistic estimate of carbon emissions. Only carbon emissions $\left(\mathrm{CO}_{2}\right)$ were used to determine the environmental impact of modal choice decisions, which may be viewed as a limitation to the study. Other emissions, including particle matters (PM) such as $\mathrm{NO}_{x}, \mathrm{SO}_{2}, \mathrm{O}_{3}$ and volatile organic compounds (VOC) 
as discussed by Swarts et al. (2012), were excluded from the calculation. This approach was used for both road and rail transport. The activity-based approach calculates carbon emissions by using the following formula (McKinnon \& Piecyk 2011:5-6):

$\mathrm{CO}_{2}=$ tons transported $\times$ average distance travelled $\times \mathrm{CO}_{2}$ emissions factor per ton-km

[Eqn 3]

The information required for this study was drawn from financial statements provided by Firm A, as well as semistructured personal and telephone interviews. The data gathered during the interviews was verified and triangulated through financial statements received.

The small sampling size of one firm (a case study approach) and the unavailability of environmental costs to do a full environmental impact study can be viewed as limitations of this research.

\section{Research results \\ Logistics costs with rail as the predominant mode of transport (2006-2008)}

Between 2006 and 2008, rail transport was the predominant mode used to move the bulk mining extract between its mine and its production facility. It received between three and four trainloads of mining extract at its production facility per week, which was sufficient to keep its production facility running without any raw material shortages. The logistics costs for the period 2006-2008 are illustrated in Table 2. It indicates that transport costs contributed by far the greatest proportion of total logistics costs.

The rail rates charged by TFR between 2006 and 2008 increased substantially and were significantly higher than the inflation rate (see Figure 5). Inflation figures used for this analysis were based on the consumer price index (CPI) and were sourced from Statistics South Africa (STATSSA 20062001). The increased transport costs contributed to Firm A's logistics costs, increasing by 30.29\% between 2006 and 2007 and by $31.86 \%$ between 2008 and 2009 .

Other factors leading to the increased logistics costs were product volume growths contributing to increased inventory holding, storage and handling costs. As transport cost is the main cost component in its logistics cost structure, it is understandable that transport decisions are important for Firm A.

\section{The move from rail to road transport}

Transnet Freight Rail (TFR) was plagued by a number of problems during 2008 and 2009. Its annual reports (Transnet 2008, 2009) highlighted these problems, which included:

- Power supply constraints were implemented throughout the country.

- Heavy rainfalls and electric storms disrupted rail operations.
TABLE 2: Logistics costs of Firm A (2006-2008).

\begin{tabular}{|c|c|c|c|}
\hline Cost item & 2006 & 2007 & 2008 \\
\hline Transport costs & R 27521367 & R 35497911 & R 46351867 \\
\hline Storage and handling costs & R 91991 & R 309486 & R 310651 \\
\hline $\begin{array}{l}\text { Management, administration } \\
\text { costs }\end{array}$ & R 554264 & R 653477 & R 825771 \\
\hline Inventory carrying costs & R 72378 & R 332045 & R 1025802 \\
\hline Total logistics costs & R 28240000 & R 36792919 & R 48514091 \\
\hline
\end{tabular}

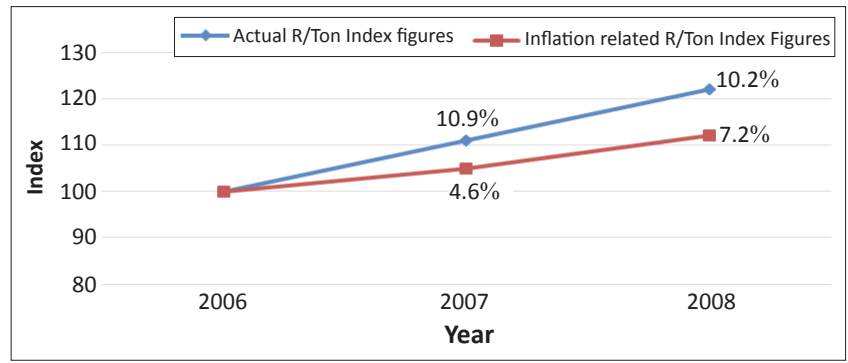

Note: Please see the full reference list of the article, Van Jaarsveld, L., Heyns, G.J. \& Kilbourn, P.J. 2013, 'Logistics opportunity costs: A mining case study', Journal of Transport and Supply Chain Management 7(1), Art. \#120, 11 pages. http://dx.doi.org/10.4102/jtscm.v7i1.120, for more information.

FIGURE 5: Actual rand/ton rates versus inflation related rand/ton rates.

- Older locomotives were retired and unused wagon types were scrapped, which gave rise to fewer assets being operational throughout the year.

- TFR was heavily impacted by the downturn in the global economy. The lower volumes transported, as well as the change in the type of commodities transported, had a major impact on TFR's operational efficiencies, with the drop in volumes transported resulting in $12 \%$ fewer trains being operated.

- The locomotives' utilisation dropped by $23 \%$ and the wagons' utilisation dropped by $20 \%$ due to the different mix of commodities being railed.

- Certain assets were mothballed due to underutilisation.

- TFR was also plagued by cable theft, which affected its rail operations. Cable theft incidents led to train cancellations, poor service delivery, reduced productivity and the loss of business.

As a result of poor service levels received from TFR, which included a lack of wagons; old malfunctioning locomotives; trains simply stopping en-route when the driver's allowable working hours were reached; and increased theft of tarpaulin, cables and signals, it was decided during 2009 to move more freight onto road to ensure that its production facility did not come to a standstill and incur huge stock-out and operational costs.

\section{Transport cost with road as the predominant mode of transport (2009-2011)}

During 2009, road transport was used on an ad hoc basis whenever TFR experienced a major disruption. These ad hoc loads came at a very high rand/ton rate; almost double the rate per ton of rail transport. As its road transport requirements were infrequent, these rates had to be accepted because the firm was not in a position to negotiate better rates with the road transport contractors. However, during 2010, a strategic decision was made to transport some of the mining extract by road to ensure continued supply to its production facility. This decision placed the firm in an improved position to negotiate 
better rand/ton rates. The fixed number of trucks required on a continuous basis placed the road transport operators in a better position to compete with rail transport. Interestingly, the rail transport costs charged by TFR increased on a rand/ ton basis, whilst the road transport costs that were negotiated with the transport contractors came down between 2009 and 2010 and remained relatively unchanged during 2011 and 2012. Figure 6 illustrates the variance between road and rail rate per ton for the period 2006-2009.

From Figure 6, it is evident that the gap between the road and rail transport rand/ton rate is diminishing. The flexibility and reliability that comes with road transport has therefore become much more affordable and is now in direct competition with rail transport volumes. Rail transport was however still significantly cheaper than road transport for the time periods examined in this study.

The disruptions experienced by TFR did not only affect the freight movements between the mine and the production facility, but also had a significant impact on freight movements directly from the mine to its customers. Until 2009, two of Firm A's biggest customers received all of their freight by rail. However, from 2010 these customers started receiving the bulk of their freight by road, with rail only being used on an ad hoc basis. Total freight movements to customers are depicted in Figure 7. It is apparent that road freight transport to customers was in decline from 2006 to 2009, whilst rail transport increased over the same period. However, since 2010, the trend has changed to the point that, in 2011, the tonnages moved by road exceeded the tonnages moved by rail for the first time.

It is noticeable that TFR's annual rate increases were not inflation related. Figure 8 indicates what the rail rand/ton rate would have been from 2006 until 2012 had the rates increased based on inflationary changes.

If Firm A was able to move all of its freight tonnage by rail during 2006 until 2011, and did not have to move a portion of its freight off rail and onto road (since 2009), a significant transport cost saving would have been attained. The cost differential between road and rail transport is illustrated in Figure 9.

It is apparent from Figure 9 that more was spent on transport costs than would have been necessary had all freight moved by rail. The longer this trend continues, the greater the cost differential becomes. Table 3 illustrates the difference in

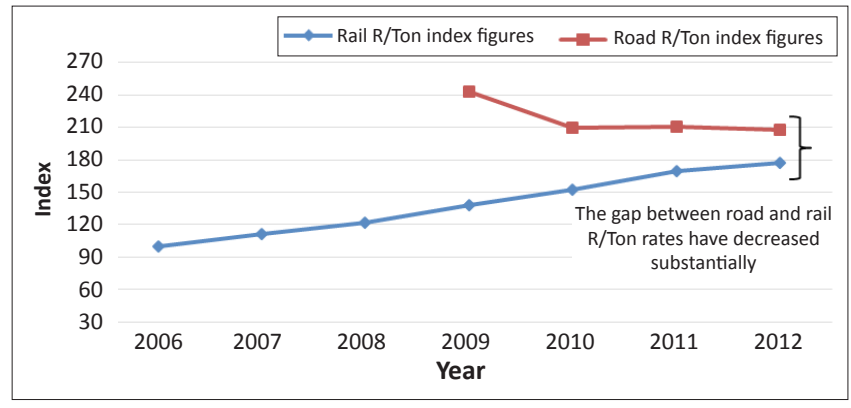

FIGURE 6: Road versus rail rand/ton rate index figures.

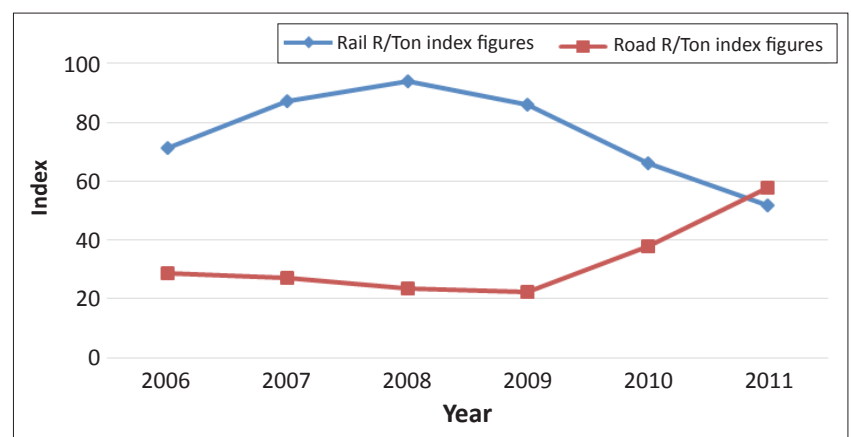

FIGURE 7: Transport to all customers index figures.

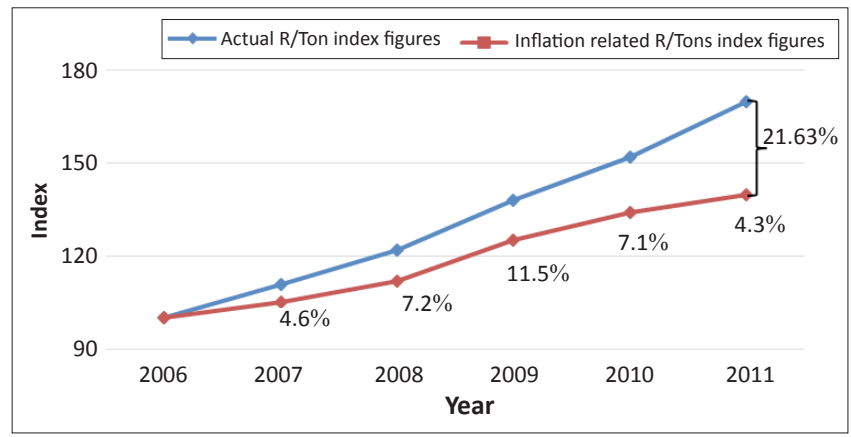

FIGURE 8: Actual and inflation-related (rail transport) rand/ton rates.

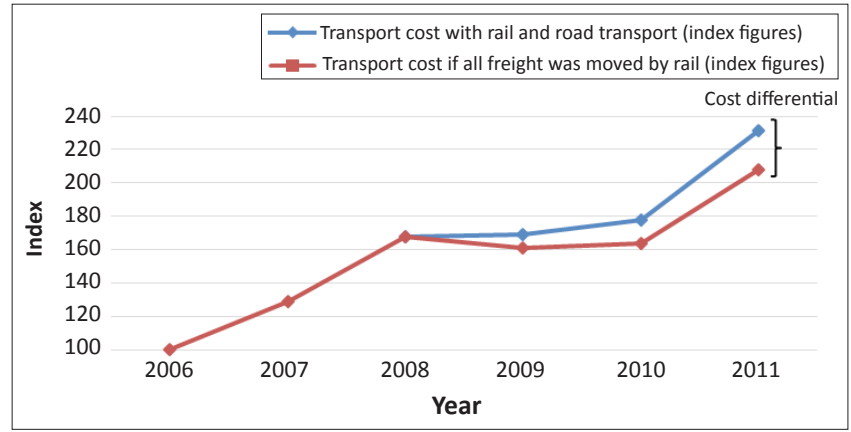

FIGURE 9: Transport costs if all freight was moved by rail.

TABLE 3: Difference in transport costs (indexed figures).

\begin{tabular}{|c|c|c|c|c|c|c|}
\hline Cost Item & 2006 & 2007 & 2008 & 2009 & 2010 & 2011 \\
\hline Rail transport cost & 100.00 & 128.98 & 168.42 & 150.10 & 128.16 & 111.90 \\
\hline Road transport cost & - & - & - & 19.14 & 49.83 & 119.59 \\
\hline If all tonnages were moved on rail & 100.00 & 128.98 & 168.42 & 160.99 & 164.30 & 208.29 \\
\hline Paid more by using road transport $(\%)$ & 0.00 & 0.00 & 0.00 & 5.12 & 8.33 & 11.14 \\
\hline
\end{tabular}


transport costs by using road transport as opposed to only using rail transport.

The impact on the firm's financial performance is also significant when comparing the different modal scenarios based on calculations using the SPM. Table 4 illustrates this variance.

If only rail transport was used for all inbound transport requirements, the firm's profit margin in 2011 would not have reduced to $8.55 \%$, but would have been $9.56 \%$. The return on assets (ROA) in 2011 would have been $18.93 \%$, as opposed to $16.93 \%$ and this represents a much better utilisation of its assets to generate sales.

\section{Logistics costs with road as the predominant mode of transport (2009-2011)}

Using the formula described earlier, the total logistics costs during 2009-2011 were calculated to determine the total logistics cost differential between only using rail transport and using both road and rail transport to move products through the supply chain. The logistics opportunity cost is estimated by determining the future value of the estimated cost differential, based on the firm's weighted average cost of capital (WACC). The total logistics costs and logistics opportunity costs are shown in Table 5.

Between 2009 and 2011, the firm's total logistics cost difference was R12 845 478. This implies that the amount of money could have been available for the firm to spend or invest elsewhere in the business, as opposed to using the more costly transport mode to move the same amount of tonnage between the mine and the production facility. The opportunity cost of using road transport is not only the cost difference between the transport mode scenarios, but it is also the potential return that could have been earned on the cost difference. If the logistics cost difference was invested at the firm's WACC the total logistics opportunity costs are estimated to have been R15 561581 over the period. As these numbers are annualised, the total logistics opportunity costs are underestimated and would have been higher if each month's logistics cost difference had been invested on a monthly basis.

\section{Impact of inventory levels}

The increased frequency of disruptions in the service delivery from TFR resulted in Firm A increasing the use of road transport during 2009 to reduce the risk of disruptions at their production facility. Typically, the firm's seven days of cover (DOC) at the production facility were replenished with between three and four block trains supplied by TFR. An analysis was done to determine how much more bulk mining extract the production facility should keep to avoid using road transport, but at the same time not put the production facility at risk should disruptions at TFR be experienced. The impact of increasing the raw material stock levels at the production facility on selected financial ratios is illustrated in Table 6.

The scenario to determine the ideal inventory level was done based on the assumption that rail, not a combination of road

TABLE 4: Ratio analysis with road and rail transport versus only rail transport.

\begin{tabular}{|c|c|c|c|c|c|c|}
\hline Year & 2006 & 2007 & 2008 & 2009 & 2010 & 2011 \\
\hline \multicolumn{7}{|l|}{ Ratio analysis with road and rail transport } \\
\hline Profit margin (\%) & 11.18 & 9.36 & 12.97 & 11.78 & 11.27 & 8.55 \\
\hline Return on assets (\%) & 21.56 & 24.47 & 31.18 & 23.93 & 19.93 & 16.93 \\
\hline Inventory turns per year & 33.36 & 26.55 & 17.23 & 18.91 & 15.06 & 16.60 \\
\hline Outbound transport as percentage of sales (\%) & 16.32 & 15.29 & 16.63 & 15.26 & 15.15 & 26.52 \\
\hline Inbound transport as percentage of sales (\%) & 12.22 & 12.62 & 11.89 & 10.08 & 10.54 & 10.08 \\
\hline Ratio analysis with rail transport only & & & & & & \\
\hline Profit margin (\%) & 11.18 & 9.36 & 12.97 & 12.27 & 12.08 & 9.56 \\
\hline Return on assets (\%) & 21.56 & 24.47 & 31.18 & 24.93 & 21.37 & 18.93 \\
\hline Inventory turns per year & 33.36 & 26.55 & 17.23 & 18.77 & 14.87 & 16.31 \\
\hline Outbound transport as percentage of sales $(\%)$ & 16.32 & 15.29 & 16.63 & 15.26 & 15.15 & 26.52 \\
\hline Inbound transport as percentage of sales (\%) & 12.22 & 12.62 & 11.89 & 9.59 & 9.73 & 9.07 \\
\hline
\end{tabular}

TABLE 5: Logistics opportunity costs of using road transport (2009-2011).

\begin{tabular}{|c|c|c|c|}
\hline Cost Item & 2009 & 2010 & 2011 \\
\hline Transport cost & R46 575954 & R48 984761 & R63 707316 \\
\hline Storage and handling cost & R197 522 & R209 219 & R185 301 \\
\hline Management and admin cost & R1 088600 & R1 239610 & R2 017321 \\
\hline Inventory handling cost & R1 051392 & R1 162740 & R1 169364 \\
\hline Total logistics costs (both road and rail transport) & R48 913468 & R51 596330 & R67 079302 \\
\hline Transport cost & R44 307825 & R45 216647 & R57 323337 \\
\hline Storage and handling cost & R197 522 & R209 219 & R185 300 \\
\hline Management and admin cost & R1 050428 & R1 157158 & R1 712690 \\
\hline Inventory holding cost & R1 051392 & R1 162740 & R1 169364 \\
\hline Total logistics cost (only rail transport) & R46 607167 & R47 745763 & R60 390691 \\
\hline Logistics cost difference & R2 306301 & R3 850567 & R6 688611 \\
\hline Logistics opportunity costs & R3 240187 & R4 830150 & R7 491244 \\
\hline
\end{tabular}


TABLE 6: The financial impact of increased inventory.

\begin{tabular}{|c|c|c|c|c|c|c|c|c|}
\hline Ratio Analysis & $7 \mathrm{DOC}$ & $8 \mathrm{DOC}$ & $10 \mathrm{DOC}$ & $12 \mathrm{DOC}$ & $14 \mathrm{DOC}$ & $16 \mathrm{DOC}$ & $18 \mathrm{DOC}$ & $20 \mathrm{DOC}$ \\
\hline Profit margin (\%) & 8.55 & 9.49 & 9.37 & 9.25 & 9.13 & 9.03 & 8.91 & 8.79 \\
\hline Return on assets (\%) & 16.93 & 18.55 & 18.05 & 17.55 & 17.07 & 16.80 & 16.34 & 15.89 \\
\hline Inventory turns per year & 16.60 & 15.66 & 14.49 & 13.49 & 12.62 & 11.89 & 11.19 & 10.59 \\
\hline Outbound transport as percentage of sales (\%) & 26.52 & 26.52 & 26.52 & 26.52 & 26.52 & 26.52 & 26.52 & 26.52 \\
\hline Inbound transport as percentage of sales (\%) & 10.08 & 9.10 & 9.16 & 9.22 & 9.28 & 9.34 & 9.40 & 9.46 \\
\hline Inventory carrying as percentage of sales (\%) & 0.43 & 0.45 & 0.48 & 0.52 & 0.55 & 0.59 & 0.63 & 0.66 \\
\hline Economic value add & 26219 & 35311 & 33065 & 30819 & 28574 & 27178 & 24932 & 22686 \\
\hline
\end{tabular}

DOC, Days of cover

TABLE 7: Carbon emissions if all freight was moved by rail.

\begin{tabular}{|c|c|c|c|c|}
\hline Year & Tons moved & Average distance travelled & Carbon emissions factor per ton-km (per kg) & Carbon emissions (in kg) \\
\hline 2006 & 211209 & 571 & 0.0316 & 3810971 \\
\hline 2007 & 245649 & 571 & 0.0316 & 4432392 \\
\hline 2008 & 291054 & 571 & 0.0316 & 5251662 \\
\hline 2009 & 262152 & 571 & 0.0316 & 4730166 \\
\hline 2010 & 227902 & 571 & 0.0316 & 4112173 \\
\hline 2011 & 258972 & 571 & 0.0316 & 4672787 \\
\hline \multicolumn{4}{|c|}{ Total carbon emissions (only rail transport) } & 27010150 \\
\hline \multicolumn{4}{|c|}{ Total carbon emissions (road and rail transport) } & 37143658 \\
\hline \multicolumn{4}{|c|}{ More carbon emissions due to road transport } & 10133516 \\
\hline
\end{tabular}

kg, kilogram

and rail, transports all bulk mining extract. As a result, the inbound transportation cost used for the 8 DOC to 20 DOC scenarios is lower than the existing seven DOC scenario; this is due to the less costly rail transport rates. However, a once-off transport cost to increase the respective minimum inventory level of bulk mining extract is required, which increases the corresponding inbound transport percentage of sales as the stock levels increase. The best financial position will be achieved by keeping eight DOCs worth of raw materials at the production facility; however, increasing the DOC by only one day will not be sufficient to mitigate the risk of not using road transport. As a result, Firm A will have to keep more than 8 DOC to ensure that the risk of not using road transport is minimised. By increasing the minimum stock level to $10 \mathrm{DOC}$, the firm will have to invest in two additional silos in order to sufficiently increase its storage capacity. At 10 DOC, the firm will turn its inventory 14.49 times a year as opposed to the current 16.60 times. As soon as the inventory is increased above 16 DOC the company's economic value add (EVA) drops to below its current level of 26 219. It will, as a result, not be in a better financial position if it were to keep more than 16 DOCs worth of bulk mining extract. The company's profit margin will increase if the company keeps 10 DOC versus 7 DOC and the company will also increase its return on assets. At 10 DOC, the company's inbound transportation costs as a percentage of sales is lower than it was at 7 DOC. Increasing its minimum inventory levels to 10 DOC should be sufficient to minimise the risk of any rail transport delays; however, the minimum level can be increased to up to 16 DOC without impacting its financial position negatively.

\section{Carbon emissions impact of using road transport}

Carbon emissions have received increased attention in all industries over the last decade. With talks of firms being taxed on their carbon emissions, it will become critical for all firms to measure their carbon emissions. The decision to move some freight off rail and onto road would have had a negative impact on the environment, as road transport is accountable for higher carbon emissions than rail transport. As mentioned previously, the activity-based approach was used to estimate the carbon emissions resulting from the choice of transport mode. The carbon emissions factor per ton-km used were United Kingdom (UK) based, as South African emission factors are not readily available.

The total transport carbon emissions for the period 2006-2011 were $37143663 \mathrm{~kg}$; this was comprised of $23643359 \mathrm{~kg}$ and $13500304 \mathrm{~kg}$ for rail and road transport respectively.

If all the freight that was moved on road had been done by rail, the carbon emissions picture would have looked significantly different. Table 8 illustrates what the carbon emissions would have looked like had all of the freight moved by rail.

It is apparent when analysing Table 7 that the carbon emissions increased substantially when the use of road transport begun. If all its freight had been moved by rail, it would have emitted $10133516 \mathrm{~kg}$ of carbon less than with its road and rail transport mix.

If these carbon emissions were taxed over these years, it would have added a significant cost to the firm and would have had a negative impact on its bottom line.

\section{Conclusion}

From the results of this case study research, it is evident that there could be significant logistics opportunity costs involved in modal choice decisions. This research entailed the calculation of the logistics opportunity costs resulting 
from a shift from rail to road transport for a relatively small organisation in the mining industry. The logistics opportunity costs, calculated over the three-year review period were substantial. This study highlights the need for firms to analyse their modal choice on a regular basis and to base their decisions not only on transport costs but total logistics cost, which include opportunity costs associated with inventory holding levels and emissions costs.

This study indicates that it is imperative for TFR to not only expand its existing capacity, but also to improve customer service to achieve the necessary modal shift from road to rail transport in order to attain the strategic objectives of their MDS. By not providing satisfactory service to customers, the customers will continue to use road transport for goods that are suitable for rail transport, which, in turn will continue to add significant costs to South Africa's logistics costs. The continuous use of road transport as opposed to rail transport will also increasingly damage the condition of our roads, which will result in excessive investment being required to repair the damage. The ripple effect of poor-quality roads will continue with transport operators' overhead costs increasing due to vehicles requiring more maintenance and repairs. These costs will add to the price of the finished goods, which will ultimately be paid by the end user. It is a well-known fact that rail transport emits less carbon emissions than road transport; as a result, the environmental impact of not having a reliable rail service should not be underestimated.

Poor TFR service delivery, which greatly influenced the decision to use road, as opposed to rail, transport had a major effect on the total logistics costs of Firm A. If this impact can be extrapolated, not only to the rest of the mining sector, but also to other industries and supply chains, where appropriate, the potential impact on the South African economy would be considerable. TFR therefore must ensure that they not only focus on expanding their existing capacity, but also focus on improving customer service to potential and existing customers. The impact on the South African economy by not having a reliable rail service is therefore significant.

A limitation of this study is that it is restricted to one relatively small company in the mining industry, only focusing on the inbound transportation portion of its supply chain. Opportunity costs associated with the so-called 'last mile' component of the supply chain were also not considered, thus excluding costs associated with customer service, such as lost sales. Further studies are required to explore the logistics opportunity costs of using road in place of rail transport in other industries in the South African economy.

\section{Acknowledgements Competing interests}

The authors declare that they have no financial or personal relationship(s) that may have inappropriately influenced them in writing this article.

\section{Authors' contributions}

L.v.J. (University of Johannesburg), G.J.H. (University of Johannesburg) and P.J.K. (University of Johannesburg) contributed equally to the writing of this article.

\section{References}

Anupindi, R., Chopra, S., Deshmukh, S.D., Van Mieghem, J.A. \& Zemel, E., 2004 Managing Business Process Flows. Principles of Operations Management, Pearson, New Jersey.

Atrill, P. \& McLaney, E., 2008, Accounting and Finance for Non-Specialists, 6th edn., Pearson, London.

Behrens, K. \& Picard, P.M., 2011, 'Transportation, freight rates, and economic geography', Journal of International Economics 85(2), 280-91. http://dx.doi. org/10.1016/j.jinteco.2011.06.003

Bromley, D. \& Foltz, J., 2011, 'Sustainability under siege: Transport costs and corruption on West Africa's trade corridors', Natural Resources Forum 35(1), 32-48. http:// dx.doi.org/10.1111/j.1477-8947.2011.01342.x

Burton, D. \& Bartlett, S., 2005, Practitioner Research for Teachers, SAGE Publications, London, viewed 24 October 2012, from http://srmo.sagepub.com/view/ practitioner-research-for-teachers/d9.xml

BUSA, 2011, Road Freight Strategy for South Africa - BUSA Comments, viewed 03 August 2011, from http://www.agbiz.co.za/LinkClick.aspx?fileticket=a2\%2FMBHt lo20\%3D\&tabid $=113$

Chopra, S. \& Meindl, P., 2010, Supply Chain Management - Strategy, Planning and Operation, 4th edn., Prentice Hall, New Jersey.

Coyle, J.J., Bardi, E.J. \& Langley, C.J., 2003, The Management of Business Logistics a Supply Chain Perspective, 7 th edn., South-Western Cengage Learning, Canada.

Coyle, J.J., Langley, C.J., Novack, R.A. \& Gibson, B.J., 2013, Managing Supply Chains a Logistics Approach, 9th edn., Thomson South Western, Canada.

Department of Transport, 2005a, Road Infrastructure Strategic Framework for South Africa, viewed 08 August 2011, from http://www.transport.gov.za/library/docs/ rifsa/intro.html

Department of Transport, 2005b, The National Freight Logistics Strategy, viewed 04 April 2012, from http://www.freetrans.gov.za/documents/advert/5.\%20 National_Freight_Logistics_Strategy.pdf.

Department of Transport, 2011, Road Freight Strategy for South Africa, viewed 02 July 2012, from http://www.agbiz.co.za/LinkClick.aspx?fileticket=xCBSZIz9nfo\%3 D\&tabid $=113$

Du Toit, E., Erasmus, P., Kotzé, L., Ngwenya, S., Thomas, K. \& Viviers, S., 2010, Corporate Finance: A South African Perspective, Oxford University Press, Cape Town.

eNatis, 2007-2012, Live vehicle population, viewed 06 July 2012, from http://www. enatis.com

Gattorna, J.L. \& Walters, D.W., 1996, Managing the Supply Chain. A Strategic Perspective, Macmillan, London.

Havenga, J., 2010, 'Logistics Costs in South Africa - The Case for Macroeconomic Measurement', South African Journal of Economics, 78, 460-76. http://dx.doi. org/10.1111/j.1813-6982.2010.01252.x

Havenga, J. \& Pienaar, W.J., 2012, 'Quantifying freight transport volumes in developing regions: Lessons learnt from South Africa's experience during the 20th century', Economic history of developing regions 27(2), 87-113. http://dx.doi.org/10.1080 Economic history of developi
/20780389.2012.745666

Havenga, J., Simpson, Z. \& De Bod, A., 2012, 'South Africa's domestic intermodal imperative', Research in Transportation Business and Management 5, 38-47. http://dx.doi.org/10.1016/j.rtbm.2012.11.006

Havenga, J. \& Simpson, Z., 2013, 'National logistics costs and global trends', 9th State of Logistics survey for South Africa 2012, pp. 2-19, CSIR, Pretoria.

Lambert, D.M., Stock, J.R. \& Ellram, L.M., 1998, Fundamentals of Logistics Management, McGraw-Hill, Singapore.

Langley, C.J., Coyle, J.J, Gibson, B.J., Novack, R.A. \& Bardi, E.J., 2008, Managing Supply Chains: A Logistics Approach, 8th edn., International student edn., South-Western Cengage Learning, Canada.

McKinnon, A. \& Piecyk, M., 2011, Measuring and managing $\mathrm{CO}_{2}$ emissions of European Chemical Transport, Brussels, Cefic - European Chemical Industry Council.

Osorio, A.F. \& Toro, H.H., 2012, 'An MIP model to optimize a Colombian cash supply chain', International Transactions in Operational Research 19(5), 659-73. http:// dx.doi.org/10.1111/j.1475-3995.2011.00850.x

Pienaar, W.J. \& Vogt, J.J., 2012, Business Logistics Management. A Value Chain Perspective, 4th edn., Oxford University Press, Cape Town.

Republic of South Africa, 1930, Motor Carrier Transportation Act, Act 39 of 1930, Government Printers, Pretoria.

Republic of South Africa, 1988, Transport Deregulation Act, Act 80 of 1988 , Government Printers, Pretoria.

SABITA, 2012, The Cost of SA's deteriorating roads, viewed 25 July 2012, from http:// www.sabita.co.za/

Sahay, B.S., Cavale, V. \& Mohan, R., 2003, The 'Indian' supply chain architecture, viewed 20 October, from http://time.dufe.edu.cn/wencong/supplychain/001.pdf 
Satar, N.M. \& Peoples, J., 2010, 'An empirical test of modal choice and allocative efficiency: Evidence from US coal transportation', Transportation research part $E$ : Logistics and Transportation Review 46(6), 1043-56. http://dx.doi.org/10.1016/j. tre.2010.01.003

STATSSA, 2006-2011, Consumer Price Index (CPI), viewed 25 September 2012, from http://www.statssa.gov.za/keyindicators/cpi.asp

Swarts, S., King, D., Simpson, Z., Havenga, J. \& Goedhals-Gerber, L., 'Calculation of freight externality costs for South Africa', Journal of Transport and Supply Chain Management 6(1), 207-222.

Transnet, 2004, Transnet Limited Annual Report, viewed 28 June 2012, from http:// www.transnet.net/InvestorRelations/Transnet\%20Reports/Transnet\%20 Annual\%20Report\%202004\%20-\%202005\%20.pdf

Transnet, 2005, Transnet Limited Annual Report, viewed 28 June 2012, from http:// www.transnet.net/InvestorRelations/Transnet\%20Reports/Transnet\%20 Annual\%20Report\%202005\%20-\%202006\%20.mht

Transnet, 2006, Transnet Limited Annual Report, viewed 28 June 2012, from http:// www.transnet.net/InvestorRelations/Transnet\%20Reports/Transnet\%20 Annual\%20Financial\%20Results\%20Report\%202006\%20-\%202007\%20.pdf

Transnet, 2007, Transnet Limited Annual Report, viewed 28 June 2012, from http:// www.transnet.net/InvestorRelations/Transnet\%20Reports/Transnet\%20 Annual\%20Financial\%20Report\%202007\%20-\%202008\%20.pdf
Transnet, 2008, Transnet Limited Annual Report, viewed 29 July 2012, from http:// www.transnet.net/InvestorRelations/TransnetRep.aspx

Transnet, 2009, Transnet Limited Annual Report, viewed 28 June 2012, from http:// www.transnet.net/InvestorRelations/TransnetRep.aspx

Transnet, 2011, Transnet Limited Annual Report, viewed 29 June 2012, from http:// www.transnet.net/InvestorRelations/TransnetRep.aspx

Transnet, 2012a, Transnet Limited Annual Report, viewed 12 July 2012, from http://www.transnet.net/PressOffice/Transnet\%20presentations/Transnet\%20 results\%202012\%20presentation_final.pdf

Transnet, 2012b, Transnet Market Demand Strategy, viewed 16 June 2012, from http://www.transnet.net/InvestorRelations/Documents/20120409\%20MDS\%20 launch\%20presentation.pdf

University of South Florida, n.d., Analysis of Freight Movement Mode Choice Factors, viewed 26 August 2012, from http://www.dot.state.fl.us/rail/Publications/ Studies/Planning/ModeChoiceFactors.pdf

Van der Mescht, J., 2006, Revisiting the Road versus Rail Debate, viewed 24 August 2012, from http://www.repository.up.ac.za/handle/2263/6100

Wajcharapornjinda, P. \& Chiadamrong, N., 2010, 'Quantifying opportunity costs in a supply chain', in Sirindhorn International Institute of Technology of Thammasat University Thailand (ed.), Proceedings of the Service Systems and Service Management, 7th International conference, Tokyo, Japan, June 28-30, 2010, pp. 603-608 